\title{
Fish diversity of $L$ aster stream, a major tributary of river $M$ andakini in Central Himalaya (India) with regard to altitude and habitat specificity of fishes
}

\section{Gurnam Singh and N. K. A garwal*}

Fish Reproduction and Conservation Biology Research Lab., Department of Zoology, School of Life Science, H.N.B. Garhwal University Campus Badshshithaul-249 199, Tehri Garhwal (Uttarakhand), INDIA

*Corresponding author. E-mail: agarwalnareshk3@rediffmail.com

Received: J une 4, 2013; Revised received: August 4, 2013; Accepted: August 22, 2013

Abstract: Laster stream is a major tributary of river Mandakini, which in turn is a major tributary of river Alaknanda. Stream traverses a distance of $\sim 40 \mathrm{~km}$ before joining with river Mandakini at Suryaprayag (Tilwara) in Rudraprayag district (Uttarakhand), India. Present study reports existence of twenty one indigenous fish species belonging to eight genera, three families and two orders from the Laster stream. Schizothorax richardsonii (Cyprinidae family) was the dominating species followed by S. plagiostomus, Barilius sp., Tor sp., Noemacheilus sp., Pseudecheneis sp., Glyptothorax sp. The distribution pattern (diversity and abundance) of these species had negative co-relation with the increase in stream altitude. Habitat conditions in the stream varied considerably from headwater to main stream. Present study also describes the habitat specificity of fish assemblage. Maximum species diversity (18 species) was recorded from pool habitat and was the most preferred habitat. Least species diversity (09 species) was recorded from cascade habitat. Riffle and rapid habitat recorded no difference in species diversity.

Keywords: Fish diversity, Stream habitat, Stream gradient, Substratum heterogeneity

\section{INTRODUCTION}

Garhwal region (Latitude $29^{\circ} 26^{\prime}$ to $31^{\circ} 28^{\prime} \mathrm{N}$ and longitude $77^{\circ} 49^{\prime}$ to $86^{\circ} 06^{\prime} \mathrm{E}$ ) of Central Himalaya is an expanse of variety of landscapes and fishery resources. The region is drained by a number of large rivers viz- Alaknanda, Mandakini, Pinder, Nandakini, Dhauliganga, Bhagirathi and Bhilangana, which later gives origin of mighty river -Ganges. A number of small streams or rivulets locally called as gads contribute their water to these large rivers. Laster stream (right bank tributary of river Mandakini) is also one of them having total catchment area $\sim 272 \mathrm{~km}^{2}$ and traverses a total length of $\sim 40 \mathrm{~km}$. Most of the small important streams of upper Ganga river system in Garhwal Himalaya remain unnoticed from fish diversity and river ecology view point. However some work has been conducted by Badola (1975), Sharma (1984), Singh et al. (1987), Dobriyal and Kumar (1988), Bisht et al. (2009); Agarwal et al. (2011); Agarwal and Singh (2012) on the ecology and fish fauna of some of the tributaries of Ganga river system. Small hill-streams are highly torrential with huge altitudinal variation. These streams provide variety of habitat for subsistence of varied and large fish fauna. The habitat has been identified as one of the primary criteria on which many biological communities are organised (Schoener, 1974; Galacaoes et al., 1996). The work on fish assemblage in relation to their habitat preference/requirements has been done in some lower western Himalayan streams (Johal et al., 2002) and in few streams of Western Ghats (Arunachalam et al., 1997; Johnson and Arunachalam, 2010). However, the work on the streams of Central Himalaya (Garhwal region) is very meagre. Therefore, an attempt has been made to study the fish diversity of Laster stream, a tributary of river Mandakini in Central Himalaya with regard to altitude and habitat preference of fishes.

\section{MATERIALS AND METHODS}

Study area: The study area lies in Laster stream - a spring fed perennial tributary of Mandakini river system (Fig. 1). It originates from Kinkholakhal at an elevation of $3620 \mathrm{~m}$ asl. The stream flows in east south direction before joining with river Mandakini at Tilwara (Rudraprayag). The stream has high gradient (720-3620 masl). It has fast flowing water $\left(0.60-2.0 \mathrm{~m}^{\mathrm{s}}\right)$. Stream is narrowed in upper course, widening towards its joining with river Mandakini. Substratum of stream consists of boulders cobbles, pebbles and diminutive sand particles. Habitat heterogeneity (pool, run, riffle, rapid, and cascade) is a characteristic feature of the stream. .Three sampling Sites: S-1 $\left(30^{\circ} 21.11^{\prime} \mathrm{N}\right.$ and $\left.78^{\circ} 58.40^{\prime} \mathrm{E}\right)$ between Suryaprayag to Syalbu (720 - $800 \mathrm{~m}$ asl), S-2 $\left(30^{\circ} 21.49^{\prime} \mathrm{N}\right.$ and $78^{\circ}$ $\left.56.88^{\prime} \mathrm{E}\right)$ between Banoli to Patal (1080 - $1200 \mathrm{~m}$ asl) and $\mathrm{S}-3\left(30^{\circ} 25.26^{\prime} \mathrm{N}\right.$ and $\left.78^{\circ} 55.24^{\prime} \mathrm{E}\right)$, situated upstream to Kunyali (1410 - $1630 \mathrm{~m}$ asl) were selected for the study. Each site covered a stretch of $\sim 1 \mathrm{~km}$. 


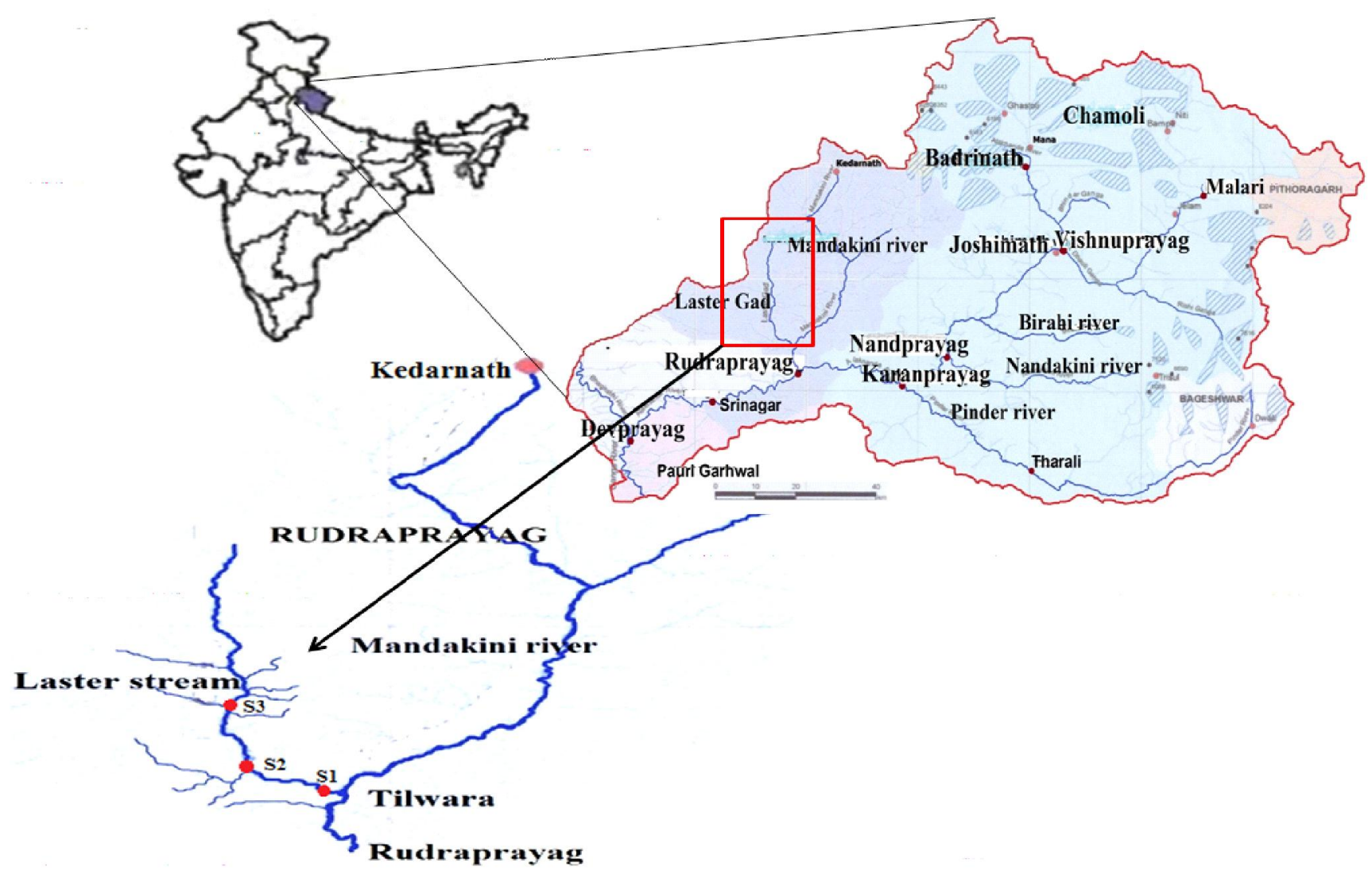

Fig. 1. Laster stream route along with its tributaries.

Sampling and analysis: Experimental fishing was done every month between morning hours to late afternoon in the five different habitats (pool, run, riffle, rapid and cascade) at each site. Fishing was done with the help of Cast net of 1-2 m diameter, mesh size 1-1.8 cm with heavy sinkers allowing net to settle down rapidly in fast flowing water, gill net (mesh size $1.2 \times 1.2 \mathrm{~cm}, \mathrm{Lx} \mathrm{B}, 12$ $\mathrm{m} \times 1.0 \mathrm{~m}$ ). In addition to these methods, Baur or Phans of 3-5 m long, scoop net, hand picking, hammering and hook and line were also used. Collected fish samples from different habitats were preserved directly into $8-10 \%$ formaldehyde solution. Subsequently fish samples were transported to laboratory for further taxonomic studies. Identification was done on the basis of morphometric and meristic characters using standard keys (Day, 1878; Tilak, 1987; Talwar and Jhingran, 1991; Badola, 2009; Jayaram, 2010). Stream substratum and its habitat are described following (Armantrout, 1999). Longitude, latitude and altitude of stream was recorded by using GPS. The relative abundance (RA) of fish species was worked out by the following formula.

RA $=$ Number of samples of particular species $\times 100 /$ Total number of samples.

\section{RESULTS AND DISCUSSION}

The study on preparation of fish species inventory of Laster stream, with respect to altitudinal variation and habitat preference was done during the period 2011-12. A total number of 21 fish species were recorded from the different habitats and varying altitude of entire stream. The collected species belonged to eight genera, three families and two orders. Study specifies that the Cyprinidae family (order cypriniformes) was the dominating family followed by Cobitidae (order cypriniformes) and Sisoiridae family (order siluriformes). Among Cyprinidae family Schizothorax richardsonii was dominating species followed by $\mathrm{S}$. plagiostomus, Barilius and Tor spp., while species viz. Schizothoraichthys progastus, Crossocheilus latius latius, Garra gotyla gotyla and G. lamta were found rarely in the stream but were common in the mainstream (Mandakini river).

Distribution pattern along thealtitudinal variation: The occurrence of fish species and their relative abundance is related with number of factors viz. flow rate, nature of substratum, water temperature, water depth, availability of food, physico-chemical properties and stream length (Agarwal and Singh, 2012). Present attempt admirably focused on the relationship between fish diversity and their relative abundance with respect to altitudinal variation. There was a negative correlation between stream altitude and species diversity as well as relative abundance. All three sampling sites have average altitude variation of 300 masl. The decrease in fish diversity was 
recorded from sampling sites S-1 to S-3. Sampling site S1 at an elevation of (720 - 800 masl) recorded high fish diversity ( 20 species) and site S- 2 at an elevation of (1080 - 1200 masl) recorded 18 fish species, while highly elevated (1410 - 1630 masl) site S-3 recorded comparatively low diversity (9 species) as represented in Table 1 . The calculation of relative abundance (RA) revealed that there is no significant variation in RA at first two sites ( $\mathrm{S}-1$ and $\mathrm{S}-2$ ), yet some six species showed high RA at S-2 than S1 (Table 1). Site S-3 showed significant variation in RA with respect S-1 and S-2. Suarez et al. (2011) also observed that altitude is the main determining factor. The fish diversity as well as species richness increased with decrease in altitude. The stream headwaters contained far few species than to those occurring downstream (Schlosser, 1987).

The decrease in diversity and relative abundance with increasing altitude may be related with fast flowing currents, decrease in water temperature, and low total discharge in the upper course towards sampling site S-3.
Sarkar et al. (2011) also reported that the fish diversity increase in the lower stretches of stream due to significant contribution of number of rivulets leading to increase in the total discharge. Fish species richness generally increased with increasing stream order and was higher in the adventitious streams than in the headwater streams (Thomas and Hayes, 2006). Decreasing temperature towards upper stretch may also be the main factor for decrease in diversity and abundance of fish fauna. Some lesser barils, mahseers and Crossocheilus spp. are not able to survive beyond the temperature range of $10^{\circ} \mathrm{C}$. Badola (2009) reported that the mahseer sp. can tolerate minimum temperature range of $8^{\circ} \mathrm{C}$ while Crossocheilus sp. and lesser barrils are species of non snow fed rivers and are found in comparatively high temperature. Sehgal (1999) also observed that water temperature is an important limiting factor affecting geographical distribution and local occurrence of fish fauna within one water system.

Distribution following the habitat preference: Laster

Table 1. Relative abundance ( RA \%) of fish fauna along altitudinal variation.

\begin{tabular}{|c|c|c|c|c|}
\hline \multirow{2}{*}{$\begin{array}{l}\text { Name of the species with or der } \\
\text { and family }\end{array}$} & \multirow{2}{*}{$\begin{array}{l}\text { Common } \\
\text { name }\end{array}$} & \multicolumn{3}{|c|}{ Sampling sites } \\
\hline & & S-1 & & $\mathrm{S}-3$ \\
\hline \multicolumn{5}{|l|}{$\begin{array}{l}\text { Order Cypriniformes } \\
\text { 1. Family Cyprinidae }\end{array}$} \\
\hline Barilius barna & Fatkua & 3.105 & 2.218 & 0.00 \\
\hline B. bendelisis & Fatkua & 4.657 & 4.213 & 0.00 \\
\hline B. vagra & Fatkua & 2.440 & 2.440 & 0.00 \\
\hline Crossocheilus latius latius & Sunhera & 1.553 & 0.00 & 0.00 \\
\hline Garra gotyla gotyla & Gunthal & 0.222 & 0.666 & 0.222 \\
\hline G. lamta & Gunthal & 0.00 & 0.887 & 0.00 \\
\hline Schizothoraichthys progastus & Chongu & 0.666 & 0.00 & 0.00 \\
\hline Schizothorax plagiostomus & Asela & 5.099 & 4.879 & 0.887 \\
\hline S. richardsonii & Maseen & 6.652 & 6.652 & 1.996 \\
\hline Tor chilinoides & Mahseer & 3.548 & 2.661 & 0.00 \\
\hline T. putitora & Mahseer & 1.553 & 0.666 & 0.00 \\
\hline T. tor & Mahseer & 1.109 & 0.00 & 0.00 \\
\hline \multicolumn{5}{|l|}{ 2. Family Cobitidae } \\
\hline Noemacheilus bevani & Gadiyal & 0.666 & 1.109 & 0.444 \\
\hline N. rupicola & Gadiyal & 2.661 & 3.326 & 0.00 \\
\hline N. savona & Gadiyal & 1.109 & 1.553 & 0.00 \\
\hline N. multifasciatus & Gadiyal & 1.996 & 1.553 & 1.109 \\
\hline N. montanus & Gadiyal & 3.548 & 3.992 & 1.996 \\
\hline \multicolumn{5}{|l|}{ Order Siluriformes } \\
\hline \multicolumn{5}{|l|}{ 1. Family Sisoiridae } \\
\hline Glyptothorax cavia & Naou & 0.887 & 0.887 & 0.222 \\
\hline G. madraspatanum & Naou & 1.774 & 2.218 & 0.00 \\
\hline G. pectinopterus & Naou & 2.661 & 1.996 & 0.444 \\
\hline Pseudecheneis sulcatus & Naou & 1.105 & 2.440 & 0.887 \\
\hline Number of species reported & & 20 & 18 & 09 \\
\hline
\end{tabular}


Table 2. Habitat preference of different fish species encountered in Laster stream-a tributary of river Mandakini.

\begin{tabular}{lccccc}
\hline Name of fish species & \multicolumn{5}{c}{ Type of habitat } \\
\cline { 2 - 6 } & Pool & R un & Riffle & Rapid & Cascade \\
\hline Barilius barna & ++ & ++ & - & - & - \\
B. bendelisis & ++ & ++ & + & + & - \\
B. vagra & ++ & - & - & - & - \\
Crossocheilus latius latius & ++ & + & + & + & + \\
Garra gotyla gotyla & + & + & ++ & ++ & + \\
G. lamta & - & - & + & ++ & ++ \\
Glyptothorax cavia & + & + & + & ++ & ++ \\
G. madraspatanum & - & + & + & ++ & ++ \\
G. pectinopterus & + & - & - & + & + \\
Noemacheilus bevani & ++ & + & - & - & - \\
N. rupicola & ++ & - & - & - & - \\
N. savona & ++ & ++ & - & - & - \\
N. multifasciatus & ++ & - & - & - & - \\
N. montanus & + & + & + & + & - \\
Pseudecheneis sulcatus & - & - & + & ++ & + \\
Schizothoraichthys progastus & ++ & + & ++ & ++ & - \\
Schizothorax plagiostomus & ++ & ++ & ++ & + & + \\
S. richardsonii & ++ & ++ & ++ & ++ & + \\
Tor chilinoides & ++ & + & + & - & - \\
T. putitora & ++ & ++ & + & + & - \\
T. tor & ++ & + & - & - & - \\
\hline Species percentage in each habitat & $85.71 \%$ & $71.42 \%$ & $61.90 \%$ & $61.90 \%$ & $42.85 \%$ \\
\hline
\end{tabular}

stream was characterised by the heterogeneity in habitat type (pool, run, riffle, rapid and cascade) at all three sampling sites. Each habitat type determined the habitat preference of different fish species. Pool types of habitats have recorded greater diversity (18 species) along with high abundance than the other habitat types, indicating that the pool habitat is preferred habitat of most of species inhabiting the Laster stream (Table 2). Diversity in run type of habitat was found close to that of riffles, while riffles and rapids having comparatively high turbulence and high velocity than runs recorded equal number of fish species. Least diversity was recorded from cascade type of habitat. Among all reported species, shoals of lesser barils preferred prominently the pool and run type of habitats having shallow water with moderate velocity except Barilius vagra restricting only to pools. Harvey and Stewart (1991) reported that minnows survive longer in pools. Crossocheilus sp. preferred the pool habitat and was occasionally found in other habitat types. Garra, Glyptothorax and Pseudecheneis spp. having special adhesive organs prominently preferred the rapid and cascade habitat, which have comparatively high turbulence and velocity (Singh and Agarwal, 1991, 1993; Singh et al., 1993). Johal et al. (2002) was of similar opinion that these true hill stream fishes are from the fast currents of rapids. Aggregations of small sized loaches
(Noemacheilus spp.) are found restricted to pools (especially to side pools) and were recorded accidently from runs. In order to minimise the chances of flown away by the fast currents these small sized fishes remains along the shallow areas of stream margins having low velocity. Observations of Finger (1982); Moyle and Baltz, (1985) and Arunachalam (2000) that small fishes are restricted to habitats that are shallow having slow currents and concentrated on along stream margins in pools and riffles, are in conformity of our findings. In contrast to this Noemacheilus savona is also recorded from the riffle habitat in present study. Snow trout (S. progastus) was not restricted to any single habitat type, but preferred pool, riffle and rapid habitat. Other snow trout ( $S$. plagiostomus and $\mathrm{S}$. richardsonii) preferred all defined habitat type except cascade habitat where they are reported occasionally. Similar to this snow trout distribution, Braaten and Berry (1997) found the evidence for discrete habitat guilds of fish that large fishes are evenly distributed in all the habitat type rather than a single habitat type. Tor spp. preferred the pool type habitat and was occasionally observed in the run and riffle habitat. Sehgal (1999) and Johal et al. (2002) are also of the opinion that bigger barb like Tor spp. are found in deep pools. A striking observation made during present study is that the species prefer their suitable 
habitat only after getting their appropriate size. The juvenile of most of species were observed to be restricted to pools (especially shallow side pools) having comparatively low velocity and high temperature than the deep mid stream. Thus, it may be concluded that the fish species are highly habitat specific. The pool habitat is most preferred habitat of large number of species. Pool is habited by $(85.71 \%)$ fish species followed by run $(71.42 \%)$, riffle $(61.90 \%)$, rapid $(61.90 \%)$ and cascade $(42.85 \%)$ as depicted in Table 2.

\section{ACKNOWLEDGEMENTS}

The financial support provided by University Grant Commission (UGC), New Delhi in the form of research project no. 37-199/2009(SR) is thankfully acknowledged.

\section{REFERENCES}

Agarwal, N.K. and Singh, G. (2012). Documentation of fishes and physico-chemical characters of a stream Indrawati- a spring fed tributary of river Bhagirathi at Uttarkashi (Central Himalaya, Garhwal). Environment Conservation J ournal, 13 (3): 117-124.

Agarwal, N.K., Singh, G. and Singh, H. (2011). Present status of ichthyofaunal diversity of Garhwal Himalayan river Bhilangana and its tributaries with reference to changing environment. Environment Conservation J ournal, 12 (3): 101-108.

Armantrout, N.B. (1999). Glossary of aquatic habitat inventory technology. American Fisheries Society.

Arunachalam, M. (2000). Assemblage structure of stream fishes in the Western Ghats (India). Hydrobiologia, 430: 1-31.

Arunachalam, M., Madhusoodanan, K., Nair, C., Vijverberg, J. and Kortmulder, K. (1997). Food and habitat partitioning among fishes in stream pools of south Indian river. International Journal of Ecology and Environmental Sciences, 23: 271-395.

Badola, S.P. (1975). Fish fauna of Garhwal hills, part II (Pauri Garhwal-U.P.). Ind. J . Zoot., 16 (1): 57-70.

Badola, S.P. (2009). Ichthyology of the central Himalaya. Transmedia Publication Media House, Bhandari Bagh, Srinagar (Garhwal), Uttarakhand.

Bisht, B., Badoni, A.K. and Bahuguna, S.N. (2009). Seasonal distribution and relative abundance of fish fauna of a small hill stream Dangchaura (Takoli) Gad, along with River Alaknanda. O ur nature, 7: 182-186.

Braaten, P.J. and Berry, C.R. (1997). Fish association with four habitat types in a south Dakota Praire stream. J ournal Freshwater Ecology, 12 (3): 477-489.

Day, F. (1878). The fishes of India: being a natural history of the fishes known to inhabit the seas and freshwater of India, Burma and Ceylon. Today and Tomorrow Book Agency, New Delhi.

Dobriyal, A.K. and Kumar, N. (1988). Fish and fisheries of the river Mandakini. In: R.D. Khulbe (Ed.), Prespectives in Aquatic Biology (pp 37-340). Papyrus: Publication House, Delhi.

Finger, T.R. (1982). Fish community-habitat reactions in a central New York stream. J ournal of F reshwater E cology, 1: 343-352.
Galacatoes, K., Stewart, D.J. and Ibarra, M. (1996). Fish community patterns of lagoons and associated tributaries in the Ecuadorian amazon. Copeia, 4: 875-894.

Harvey, B.C. and Stewart, A.J. (1991). Fish size and habitat depth relationship in headwater streams, 0 ceologia, 87: 336342 .

Jayaram, K.C. (2010). The fresh water fishes of the Indian region. Narendra Publishing House, Delhi, India.

Johal, M.S., Tandon, K.K., Tyor, A.K. and Rawal, Y.K. (2002). Fish diversity in different habitats in the streams of lower middle western Himalayas. Polish J ournal of Ecology, 50 (1): $45-56$

Johnson, J.A. and Arunachalam, M. (2010). Relation of physical habitat to fish assemblages in streams of Western Ghats, India. Applied E cology and Environment Research, 8(1): 110.

Moyle, P.B. and Baltz, D.M. (1985). Microhabitat use by an as semblage of California stream fishes: developing criteria for instream flow determinations. Transactions of American Fisheries Society, 114: 695-704.

Sarkar, U.K., Pathak, A.K., Sinha, R.K., Sivakumar, K., Pandian, A.K., Panday, A., Dubey, V.K. and Lakra, W.S. (2011). Freshwater fish biodiversity in the River Ganga (India): changing pattern, threats and conservation perspectives. Rev. Fish Biol. Fisheries. 22(1): 251-272. DOI 10.1007/s11 160-011-9218-6.

Schlosser, I.J. (1987): The role of predation in age and size related habitat use by stream fishes. E cology, 68: 651-659.

Schoener, T.W. (1974). Resource partition in ecological communities. Science, 185: 27-39.

Sehgal, K.L. (1999). Coldwater fish and fisheries in the Himalayas: rivers and streams. Technical paper. No 385, Fisheries Rome, FAO : 41-63.

Sharma, R.C. (1984). Icthyofauna of the snowfed river Bhagirathi of Garhwal Himalaya. U tter Pradesh J . Zool., 4 (2): 208-212

Singh, H.R., Badola, S.P. and Dobriyal, A.K. (1987). Geographical distribution list of Icthyofauna of Garhwal Himalaya with some new records. J. Bombay Nat. Hist. Soc., 84(1): 126-132.

Singh, N. and Agarwal, N.K. (1991). The SEM surface structure of the adhesive organ of Pseudoechneis sulcatus McClelland (Teleosti: sisoridae) from Garhwal Himalayan hillstream. Acta Icthyologica et. Piscatorial, 21 (2): 29-35.

Singh, N. and Agarwal, N.K. (1993). Organ of adhesion in four hillstream fishes: A comparative morphology study. In: H.R Singh (Ed.), Advances in Limnology. (pp 311-316), Delhi: Narendra Publishing House.

Singh, N., Agarwal, N.K. and Singh, H.R. (1993). SEM investigation on the adhesive apparatus of Garra gotyla gotyla (Family: Cyprinidae) from Garhwal H imalaya. In: H.R. Singh (Ed.), Advances in Fish Biology. (pp 281-291), Delhi: Hindustan Publishing Corporation.

Suarez, Y.R., Souza, M.M., Ferreira, F.S., Pereira, M.J., Silva, E.A., Ximenes, L.Q.L., Azevedo, L.G., Martins, O.C. and Junior, S.E.L. (2011). Patterns of species richness and composition of fish assemblages in streams of the Ivinhema river basin, upper Parana river. Acta Limnologica Brasiliensia, 23 (2): 177-188.

Talwar, P.K. and Jhingran, A.G. (1991). Inland fishes of India 
and adjacent countries. Vols. 1 and 2, Oxford \& IBH Publishing house, New Delhi.

Thomas, D.A. and Hayes, D.B. (2006). A comparison of fish community composition of headwater and adventitious streams in a coldwater river system. J ournal of F reshwater E cology, 21(2): 265-275.

Tilak, R. (1987). The fauna of India. Pisces (Teleostomi). Sub family Schizothoracinae. Zoological Survey of India. 